exaggerated by known infant standards. In the other a response similar to that of the control infants was obtained, suggesting that calcium tolerance was now normal. Further studies of calcium tolerance in late cases of idiopathic hypercalcaemia would be of interest.

We acknowledge the helpful co-operation of Professor S. G. Graham, formerly professor of child health, University of Glasgow ; Dr. P. McArthur, of Inverness ; Dr. A. L. Speirs, of Stirling ; Dr. W. R. McAinsh, Lanarkshire ; and the paediatricians of the Royal Hospital for Sick Children and the Northern Group of Hospitals, Edinburgh, in allowing us to study patients under their care. $\mathrm{Mr}$. Shepley, of the department of medical illustration, University of Edinburgh, kindly drew the graphs.

Requests for reprints should be sent to D. G. D. Barr, Royal Hospital for Sick Children, Edinburgh 9.

\section{REFERENCES}

Barr, D. G. D., and Douglas, D. M. (1965). Lancet, 2, 1126 Black, J. A., and Bonham Carter, R. E. (1963). Lancet, 2, 745.
Cassimos, C., Tsenghi, C., Michael, S., Liaromati, A., and Metaxotou, K. (1963). Pediatrics, 32, 272.

Fellers, F. X., and Schwartz, R. (1958). New Engl. F. Med., 259, 1050. Forfar, J. O., Balf, C. L., Maxwell, G. M., and Tompsett, S. L. (1956). Lancet, 1, 981.

Forfar, J. O., Tompsett, S. L., and Forshall, W. (1959). Arch. Dis. Childh., 34, 525 .

Harris, F., Hoffenberg, R., and Black, E. (1965). Metabolism, 14, 1101.

Harrison, H. E. (1959). Fed. Proc., 18, 1085.

Isaksson, B., Lindholm, B., and Sjögren, B. (1967). Metabolis

Issaksson, B., and Ohlsson, L. (1967). Metabolism, 16, 314.
Isaksson, B., and Siögren, B. (1967). Metabolism, 16, 295.

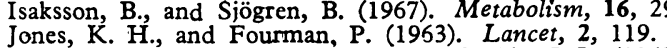

Joseph, R., Mande, R., Job, J.-C., and Corbin, J.-L. (1963). Arch. franç. Pédiat., 20, 699 .

Kenny, F. M., Aceto, T., Purisch, M., Harrison, H. E., Harrison, H. C., and Blizzard, R. M.'(1963). Ұ. Pediat., 62, 531 .

Lindquist, B. (1962). Acta paediat. (Uppsala), 51, Suppl. No. 135, p. 144 Lowe, C. E., Bird, E. D., and Thomas, W. C. (1962). F. clin. Endocr., 22, 261 .

McCredie, D. A., and McIntyre, I. P. (1968). Aust. paediat. F., 4, 47.

McCredie, D. A., and Mcintyre, I. P. (1968), Aust.

Morgan, H. G., Mitchell, R. G., Stowers, J. M., and Thomson, J. (1956). Lancet, 1, 925 .

Peacock, M., Knowles, F., and Nordin, B. E. C. (1968). Brit. med. F., 2, 729.

Vaandrager, G. J., and Weyers, H. A. (1963). Ann. paediat. (Basel), 201, 287.

Wilkinson, R. H. (1957). 7. clin. Path., 10, 126.

\title{
Sudden Failure of Swimming in Cold Water
}

\author{
W. R. KEATINGE,* M.A., M.B., PH.D. ; C. PRYS-ROBERTS, † M.B., PH.D., F.F.A. R.C.S. \\ K. E. COOPER, $\ddagger$ M.A., M.B., M.SC. ; A. J. HONOUR,§ M.A., D.PHIL.; J. HAIGHT,\| B.A.
}

Brit. med. F., 1969, 1, 480-483

\begin{abstract}
ummary : To investigate the effect of cold water on swimming four men who declared themselves good swimmers were immersed fully clothed on separate days in water at $23.7^{\circ}$ and $4.7^{\circ} \mathrm{C}$. The time that they were able to swim in the cold water was much shorter than in the warm. The two shortest swims ended after 1.5 and 7.6 minutes, before rectal temperature fell, when the men suddenly floundered after developing respiratory distress with breathing rates of $56-60 / \mathrm{min}$. The other cold swims, by the two fattest men, ended less abruptly with signs of general and peripheral hypothermia.

It is concluded that swimming in cold water was stopped partly by respiratory reflexes in the thin men and hypothermia in the fat, and partly by the cold water's high viscosity. The longer swimming times of the fat men are attributed largely to their greater buoyancy enabling them to keep their heads above water during the early hyperventilation.
\end{abstract}

The findings explain some reports of sudden death in cold water. It is clearly highly dangerous to attempt to swim short distances to shore without a life-jacket in water near $0^{\circ} \mathrm{C}$.

\section{Introduction}

Most deaths after shipwreck result from immersion hypothermia (Molnar, 1946 ; McCance et al., 1956 ; Keatinge, 1965), but most deaths in inland waters are too rapid for this. For

* Now Reader in Physiology London Hospital, London E.1.

† First Assistant, Nuffield Department of Anaesthetics, Radcliffe Infirmary, Oxford.

¥ Assistant Director, M.R.C. Body Temperature Research Unit, Radcliffe Infirmary, Oxford.

$\checkmark$ Research Officer, Department of the Regius Professor of Medicine, Radcliffe Infirmary, Oxford

II Medical Research Council Scholar, Radcliffe Infirmary, Oxford. example, a good swimmer aged 20 recently disappeared within five minutes while he was trying to swim 50 yards (46 metres) to shore from an overturned dinghy in the calm water of a reservoir at $10-11^{\circ} \mathrm{C}$. (Keatinge, 1969). Such accidents are often ascribed to cramp. However, sudden cooling of the skin causes breathlessness, which is accompanied by severe and of ten uncontrollable reflex hyperventilation (Keatinge and Nadel, 1965). This does not normally harm healthy people supported in cold water, but it seemed possible that it might prevent them from swimming.

The present experiments were designed to see whether good swimmers with clothes of a type worn by small-boat sailors could swim as far in water near $0^{\circ} \mathrm{C}$. as in warmer water, and to see what eventually stopped them. Respiratory and temperature measurements were made by means that interfered as little as possible with respiration and with swimming.

\section{Procedure and Methods}

The subjects were four men aged 24 to 36 who declared themselves to be good swimmers. Subjects 1 and 4 were physiologists involved in the experiments, subject 3 was a student, and subject 2 an amateur dinghy sailor. Medical examination showed all of them to be free of cardiovascular or respiratory disease. Heights and weights were recorded and skinfold thicknesses were measured by callipers (John Bull British Indicators Ltd.) at four standard sites: biceps mid-way between acromion process and medial epicondyle of the elbow, subscapular over the lower corner of the scapula, abdominal $5 \mathrm{~cm}$. below and lateral to the umbilicus, and subcostal at the lower border of the ribs below the mid-point of the clavicle.

Each man was immersed twice, first in an indoor swimming pool (water temperature $23.7^{\circ} \mathrm{C}$., air $20.3^{\circ} \mathrm{C}$.) and three weeks later (in March) in an outdoor pool (water temperature $4.7^{\circ} \mathrm{C}$., 
air $11.0^{\circ}$ C.). They wore a woollen shirt, jacket with zip fastener, trousers, underpants, socks, gloves, and gym shoes. A rope was tied round the waist and held by an observer so that the subject could be pulled from the water at once if necessary. Subject 4 swam without recording leads to avoid any encumbrance from these. With the other subjects a thermocouple was attached to the chest over the centre of the sternum, its junction touching the skin but not covered by sticking plaster, and another was used to measure rectal temperature at a depth of $6 \mathrm{~cm}$. Ventilation was measured with a heated screen pneumotachograph (Godart CP1) recording outflow only. The flow signal was integrated electrically breath-by-breath to give tidal volumes. The subject wore a nose clip and breathed into a mouthpiece (internal cross-section 1.8 sq. $\mathrm{cm}$.) and valve assembly; the outflow valve led via flexible tubing to the pneumotachograph head mounted on a metal boom carried by one of the observers. The boom also carried leads from the subject to stationary recording apparatus. E.C.G. leads were attached to forehead and chest (sternum), but artifacts allowed satisfactory E.C.G. records to be made in the water for only short periods. The flow and volume signals from the tachograph and the output of the E.C.G. were displayed on a Devices four-channel recorder. The output of the thermocouples was read from galvanometers (Ellab and Scalamp).

In each experiment the subject sat quietly in air for five minutes while resting temperature, air flow, tidal volume, and E.C.G. were recorded. He then climbed quickly down a ladder into the water, kept still holding the side for 45 seconds, and was then told to swim just as he would if he were trying to reach a distant shore after a boat accident. He swam within a few feet of the edge of the pool, turning every 18 metres to keep within the range of the recording leads. All were told that the experimenters would end the immersion at 12 minutes or (except for Subject 4) when the subject cooled to an extent that presented any danger. They were told that they should otherwise keep swimming until they found it impossible to swim further.

\section{Results}

\section{Control Immersions}

In the control immersions $\left(23.7^{\circ} \mathrm{C}\right.$.) three of the four men swam without discomfort for the full 12 minutes, and said that they could have continued much longer if asked to do so. The other, the thinnest (Subject 3, Table I), was not able to swim so long. From the start he was seen to have to swim

TABLE I.-Details of Subjects

\begin{tabular}{|c|c|c|c|c|c|c|c|c|}
\hline \multirow{2}{*}{$\begin{array}{l}\text { Sub- } \\
\text { ject }\end{array}$} & \multirow{2}{*}{$\begin{array}{c}\text { Age } \\
\text { in } \\
\text { Years }\end{array}$} & \multirow{2}{*}{$\begin{array}{l}\text { Height } \\
\text { (cm.) }\end{array}$} & \multirow{2}{*}{$\begin{array}{c}\text { Weight } \\
\text { (kg.) }\end{array}$} & \multicolumn{5}{|c|}{ Skinfold Thicknesses (mm.) } \\
\hline & & & & Biceps & $\begin{array}{c}\text { Sub- } \\
\text { scapular }\end{array}$ & Abdominal & $\begin{array}{l}\text { Sub- } \\
\text { costal }\end{array}$ & Mean \\
\hline $\begin{array}{l}1 \\
2 \\
3 \\
4\end{array}$ & $\begin{array}{l}24 \\
29 \\
24 \\
36\end{array}$ & $\begin{array}{l}185 \\
183 \\
173 \\
185\end{array}$ & $\begin{array}{l}74 \\
77 \\
71 \\
83\end{array}$ & $\begin{array}{l}3.4 \\
6.7 \\
3.6 \\
7.6\end{array}$ & $\begin{array}{r}10.2 \\
11.3 \\
9.2 \\
13.0\end{array}$ & $\begin{array}{r}6.8 \\
10.5 \\
7 \cdot 1 \\
13.5\end{array}$ & $\begin{array}{r}8.5 \\
10.2 \\
7.7 \\
14.8\end{array}$ & $\begin{array}{r}7 \cdot 2 \\
9 \cdot 7 \\
6 \cdot 9 \\
12 \cdot 2\end{array}$ \\
\hline
\end{tabular}

more energetically than the fatter men to keep his head above water, and in the eighth minute he became too exhausted to continue and grabbed the side of the pool.

Readings were obtained from Subjects 1 to 3 . Their skin temperatures dropped to $24-25^{\circ} \mathrm{C}$. within two minutes of the start of the swim and remained at that level thereafter (see Chart). Pulmonary ventilation in Subjects 1 and 2 rose to about $30 \mathrm{l} . / \mathrm{min}$. as they swam, with almost proportionate increases in rate of breathing. In Subject 3 both ventilation and rate rose more rapidly, reached $60-801 . / \mathrm{min}$. and $30-40$ breaths/
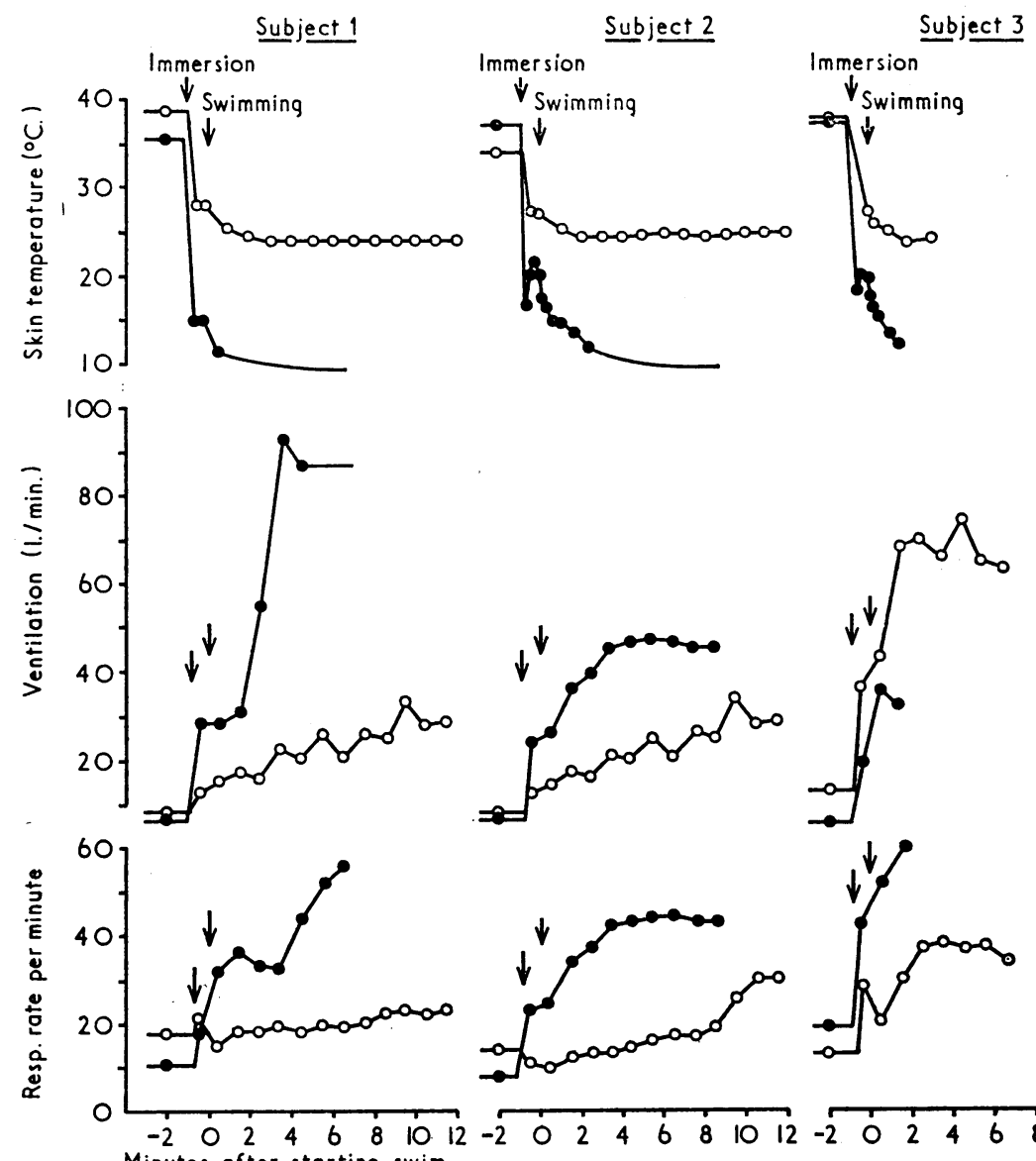

Skin temperature, ventilation, and rate of breathing before and during swims. O - - O warm water $\left(23 \cdot 7^{\circ} \mathrm{C}\right.$. $)$. 0 cold water $\left(4 \cdot 7^{\circ} \mathrm{C}\right.$.).

min. in the third minute, and remained at these levels until he gave up from exhaustion in the eighth minute.

\section{Cold Immersions}

In the cold immersions $\left(4.7^{\circ} \mathrm{C}\right.$.) all subjects experienced discomfort and difficulty in breathing as soon as they entered the water. During the 45 seconds that they kept still these sensations decreased as the water under their clothing warmed; skin temperatures, which fell to $15-18^{\circ} \mathrm{C}$. immediately after immersion, usually rose a few degrees during this 45 -second period. When they started to swim the skin temperatures fell again and were always below $12^{\circ} \mathrm{C}$. by the end of the third minute.

None of the men was able to swim in the cold water for the full 12 minutes. At the start they swam higher in the water and with more energetic and uneven movements than in the control swims. They then slowed down and sank progressively lower in the water so that mean swimming speeds were virtually the same as in the control immersions (Table II).

In the two shortest swims in cold water the end was abrupt. Subject 1 spat out his mouthpiece after swimming for just over five minutes, in order to ease his breathing, and after swimming 
for a further two and a half minutes with increasing difficulty he inhaled a little water, floundered, grabbed at the side of the pool, and was pulled ashore. The end of Subject 3's swim was even more sudden. After swimming for only one and a half minutes he floundered and sank without managing to reach the side of the pool, which was about 1 metre from his head, and had to be pulled ashore. Within one minute of leaving the water both of these subjects were alert, cheerful, and shivering very little. Both said that shortness of breath and general fatigue had prevented them from swimming further. The records showed that their respiration was very rapid by the time they stopped swimming. Subject 1's rate of breathing had risen to $56 / \mathrm{min}$. and his pulmonary ventilation to 931 ./ min. by the end of the swim. Subject 3's rate of breathing had risen as high as $60 / \mathrm{min}$; his ventilation was lower than the high values reached at the end of his control swim, probably because tidal volume near the end of the cold swim was limited by his very high rate of breathing and by reflex inhibition of expiration due to stimulation of cutaneous cold receptors (Keatinge and Nadel, 1965). Neither subject suffered a fall in rectal temperature during these short swims; Subject 1's rectal temperature was $37.4^{\circ} \mathrm{C}$. and Subject 3 's was $36.8^{\circ} \mathrm{C}$. both before and at the end of their swims.

TABLE II.-Swimming Time, Distance, and Speed

\begin{tabular}{|c|c|c|c|c|c|c|}
\hline \multirow[b]{2}{*}{ Subject } & \multicolumn{3}{|c|}{$23.7^{\circ} \mathrm{C}$. Immersions } & \multicolumn{3}{|c|}{$4.7^{\circ} \mathrm{C}$. Immersions } \\
\hline & $\begin{array}{c}\text { Swimming } \\
\text { Time } \\
\text { (min.) }\end{array}$ & $\begin{array}{c}\text { Distance } \\
\text { Covered } \\
\text { (m.) }\end{array}$ & $\begin{array}{c}\text { Mean } \\
\text { Speed } \\
\text { (m./min.) }\end{array}$ & $\begin{array}{c}\text { Swimming } \\
\text { Time } \\
\text { (min.) }\end{array}$ & $\begin{array}{l}\text { Distance } \\
\text { Covered } \\
\text { (m.) }\end{array}$ & $\begin{array}{c}\text { Mean } \\
\text { Speed } \\
\text { (m./min.) }\end{array}$ \\
\hline $\begin{array}{l}1 \\
2 \\
3 \\
4\end{array}$ & $\begin{array}{l}>12 \\
>12 \\
7.5 \\
>12\end{array}$ & $\begin{array}{l}261 \\
225 \\
135 \\
198\end{array}$ & $\begin{array}{l}21 \cdot 8 \\
18 \cdot 8 \\
18 \cdot 0 \\
16.5\end{array}$ & $\begin{array}{r}7.58 \\
9.83 \\
1.50 \\
11.42\end{array}$ & $\begin{array}{r}144 \\
224 \\
29 \\
176\end{array}$ & $\begin{array}{l}19 \cdot 0 \\
22 \cdot 7 \\
19 \cdot 3 \\
15 \cdot 4\end{array}$ \\
\hline Mean & & 205 & $18 \cdot 8$ & & 143 & $19 \cdot 1$ \\
\hline
\end{tabular}

The two fatter subjects (Nos. 2 and 4 ) swam for longer in cold water but had to stop after 9.83 and 11.42 minutes respectively. Both reported that inability to control their breathing in time with their swimming movements had made it difficult to swim during the first few minutes in cold water. Within about seven minutes breathing had started to become easier and the initial sensations of cold and tingling in the limbs had declined, presumably because of adaptation of sense organs, but these sensations were then replaced by increasing shivering and by heaviness and clumsiness of the limbs. These increased until the men felt unable to continue, swam slowly to the ladder, and climbed out. The airflow records from Subject 2 show that his rate of breathing and ventilation rose to moderately high but not extreme levels during the first five minutes of the swim and then declined a little so that by the time he left the water they were not much higher than they had been at the end of his control swim. His rectal temperature fell from $37.1^{\circ} \mathrm{C}$. before immersion to $35.0^{\circ} \mathrm{C} .10$ minutes after he left the water ; the thermocouple was displaced at the time he left the water. Subject 4, swimming without recording leads, probably suffered similar respiratory and temperature changes, since he was seen to be breathing with difficulty when he started to swim and to be shivering hard after leaving the water.

\section{Discussion}

The times for which the men could swim in water at $4.7^{\circ} \mathrm{C}$. were not only short compared with the times for which they could swim in water at $23.7^{\circ} \mathrm{C}$. but were also short compared with the times for which they could have been expected to survive with support in water at $4.7^{\circ} \mathrm{C}$. For example, in one earlier series of experiments none of a group of five volunteers suffered large enough falls in body temperature to threaten life, or serious after-effects of any kind, as a result of repeated
20 -minute immersions in water at $5^{\circ} \mathrm{C}$., whether or not they exercised or were protected by clothing (Keatinge, 1969).

The respiratory distress that halted the two shortest cold swims can be explained largely by reflexes from cutaneous cold receptors. The breathing rates of $56-60 / \mathrm{min}$. recorded just before the end of these cold swims contrast with rates of only $20-30 / \mathrm{min}$. at a similar stage in the warmer swims. Showers at near $0^{\circ} \mathrm{C}$. cause not only reflex hyperventilation with an inspiratory shift in respiration, but a sensation of breathlessness and inability to control breathing voluntarily (Keatinge and Nadel, 1965). It is easy to understand that such reflexes might induce intolerable respiratory distress during hard physical work. The work required to swim in water at $4.7^{\circ} \mathrm{C}$. will in any case be somewhat greater than in water at $23.7^{\circ} \mathrm{C}$. because of the higher viscosity of the colder water, 1.5 centipoise (cp.) compared with $0.9 \mathrm{cp}$. This disadvantage of cold water can only be counteracted to a slight extent by its greater density of $1.000 \mathrm{~g} . / \mathrm{ml}$. compared with $0.995 \mathrm{~g} . / \mathrm{ml}$. for water at $23.7^{\circ} \mathrm{C}$., which would make it marginally easier for a swimmer to float. There is evidence that reflexly induced cardiac arrhythmias may occasionally cause sudden death of healthy young men in cold water (Keatinge and Evans, 1961 ; Keatinge et al., 1964), but only on rare occasions. The present experiments suggest that the reflex respiratory response to cold is a much more frequent hazard to life in cold water.

The two fattest men were presumably able to swim through their initial respiratory difficulty in cold water because their lower specific gravity enabled them to float with less physical exertion. The heaviness of the limbs and progressive shivering that ultimately stopped them must have resulted from local and general hypothermia. Moderate cooling of forearm muscle produced by immersing the arm in water at $18^{\circ} \mathrm{C}$. for 30 minutes slows contraction and relaxation, though it increases the endurance time for sustained contraction (Nukada, 1955; Lind, 1959). Neuromuscular conduction in the rat tail fails when local temperature falls to $4-5^{\circ} \mathrm{C}$. $(\mathrm{Li}, 1958)$, but such failure is unlikely to have occurred in the present brief experiments, since volunteers were earlier found to be able to maintain almost as high rates of energy expenditure when they exercised as hard as possible for 20 minutes in water at $5^{\circ} \mathrm{C}$. as in water at $15^{\circ} \mathrm{C}$. (see Keatinge, 1969). It appears that slowing of muscle contraction and malfunction of muscular and cutaneous sense organs due to local cooling, combined with impaired cerebral function due to general hypothermia, were sufficient to end the longer swims.

From the practical point of view the most striking finding was that none of four fit people who thought themselves to be good swimmers could cover 250 metres in water at $4.7^{\circ} \mathrm{C}$., while one of them failed to cover 30 metres. This was in spite of the water being calm and the risk of panic being minimized by their knowledge that rescue facilities were at hand. Since the early respiratory disturbance prevented all of the men from controlling their breathing soon after they started the cold swim it seems inevitable that waves breaking in their faces at this time would have put them into severe difficulty within seconds. Glaser and Hervey (1951) reported a swim lasting nine minutes in water at about $2^{\circ} \mathrm{C}$., which was ended by the experimenters. Critchley (1943) quoted a remarkable wartime report of a shipwreck survivor said to have swum for 9 to 14 hours wearing indoor clothing and an overcoat in sea-water at $-1^{\circ}$ C. Swimming endurances of this kind by very fat men present no theoretical difficulty, but are clearly exceptional.

Surgeon Commander Rawlins has brought to our notice the recent drowning of all of nine Servicemen aboard a training canoe that overturned in "icy" water of the Potomac River on 6 March 1968 ; it was stated at the court of inquiry that " nothing explains why the canoe could have capsized and why all nine men drowned." The present results, obtained at almost the same time as that accident, show that swimming time in such water is usually remarkably short. No further comments seem to be necessary to emphasize the need for the occu- 
pants of small boats to wear a life-jacket capable of keeping the face above water, and the danger in trying to swim even short distances to shore in cold water without one.

We are indebted to $\mathrm{Mr}$. B. Cobern for his skilled technical assistance.

\section{REFERENCES}

Critchley, M. (1943). Shipwreck Survivors: A Medical Study, p. 7. London.
Glaser, E. M., and Hervey, G. R. (1951). 7. Physiol. (Lond.), 115, 14P.

Keatinge, W. R. (1965). Brit. med. F., 2, 1537.

Keatinge, W. R. (1969). Survival in Cold Water: The Physiology and Treatment of Immersion Hypothermia and of Drowning, pp. 30-35. Oxford.

Keatinge, W. R., and Evans, M. (1961). Quart. 7. exp. Physiol., 46, 83 Keatinge, W. R., McIlroy, M. B., and Goldfien, A. (1964). F. appl. Physiol., 19, 1145 .

Keatinge, W. R., and Nadel, J. A. (1965). 7. appl. Physiol., 20, 65.

Li, C.-L. (1958). Amer. F. Physiol., 194, 200.

Lind, A. R. (1959). F. Physiol. (Lond.), 147, 162.

McCance, R. A., Ungley, C. C., Crosfill, J. W. L., and Widdowson, E. M. (1956). Spec. Rep. Ser. med. Res. Coun. (Lond.), No. 291

Molnar, G. W. (1946). F. Amer. med. Ass., 131, 1046.

Nukada, A. (1955). Int. Z. angew. Physiol., 16, 74.

\title{
Turner's Infantile Phenotype
}

\author{
R. R. GORDON,* M.C., M.D., F.R.C.P. ; EILEEN M. O’NEILL, $\dagger$ M.D., M.R.C.P., D.C.H.
}

Brit. med.F., 1969, 1, 483-485

\begin{abstract}
Cummary : Turner's infantile phenotype is a term used $\checkmark$ to describe infants with stigmata suggestive of Turner's syndrome. These include brawny oedema of the feet, loose neck folds, and a characteristic facies. Ten cases are described in this report. Four of these had a similar facial appearance and three had serous effusions. Two of the latter died and at necropsy no cardiac, vascular, or renal cause for the effusions was found, but the gonads in each were macroscopically reduced in size and microscopically were grossly abnormal.
\end{abstract}

\section{Introduction}

Originally Turner's syndrome consisted of dwarfism, cubitus valgus, neck webbing, and infantilism in a female who should, by age, have been mature (Turner, 1938). Wilkins and Fleischmann (1944) showed that the infantilism was due to failure of gonadal development (" gonadal dysgenesis" ; "streak gonads") and this is now an accepted part of the syndrome (Jones et al., 1966). Ferguson-Smith (1965) proposed that the failure of gonadal development was due to absence of genes on the short arm of a second sex chromosome and that the dwarfism might also be explained in this way. Certainly there is a strong association between the $45 \mathrm{X}$ chromosomal state (with all its variations) and the clinical features of Turner's syndrome (and all its "atypical" forms).

Since the original description somatic features additional to dwarfism, neck webbing, and cubitus valgus have been described and the list of these Turner stigmata is now formidable (Table I). When a young girl presents with small stature and lack of secondary sex characteristics it is usually the presence of some Turner stigmata which suggests the diagnosis of Turner's syndrome. If such a person is shown to be chromatinnegative with a $45 \mathrm{X}$ karyotype the diagnosis is almost certain. The finding of streak gonads at laparotomy is final proof. However, even when such a girl is chromatin-positive streak gonads may still be present if she is an $\mathrm{X} / \mathrm{XX}$ mosaic or has a 46XXqi karyotype. On the other hand, Turner stigmata may be associated with perfectly normal ovarian development in an XX girl-the syndrome of Ullrich (Polani, 1961). In

* Consultant Paediatrician, Children's Hospital, Sheffield 10. t Consultant Paediatrician, Barnsley Group of Hospitals. such cases the Turner stigmata are probably genetically rather than chromosomally determined (Nora and Sinha, 1967).

$$
\text { TABLE I.-Turner Stigmata (Haddad and Wilkins, 1959) }
$$

\begin{tabular}{l|l} 
*1. Shield chest & *11. Lymphoedema \\
2. Overweight & 12. Cutis laxa \\
*3. High palate & 13. Keloid formation \\
*4. Micrognathia & 14. Coarctation of aorta \\
*5. Epicanthus & 15. Mental retardation \\
*6. Low-set ears & 16. Intestinal telangiectasia \\
*7. Hypoplasia of nails & 17. Deafness \\
8. Osteoporosis & 18. Short fourth metacarpals \\
9. Pigmented moles & 19. Urinary tract anomalies \\
10. Hypertension & * These features make up Turner's infantile phenotype.
\end{tabular}

Turner stigmata may also be present in males, but the expression "male Turner's syndrome" has always been contradictory and unsatisfactory.

Even in the older child, therefore, the nomenclature is confusing, but in the younger child it is more so. This is because we do not measure height and sexual maturation definitively until the teenage years. Yet it is obviously of importance to diagnose early those children who will later have Turner's syndrome, before the age at which they will require treatment. The earlier the diagnosis is made the easier should be the management and the more satisfactory the treatment.

The Bonnevie-Ullrich syndrome describes infant females with some Turner stigmata. The ones most commonly found are indicated in Table I. Such infants are not unduly short and it is not until about the age of 5 years that dwarfism can be clearly seen (Wilkins, 1965). They will, however, often be chromatin-negative and have $45 \mathrm{X}$ chromosomes. But can we say they have Turner's syndrome ? At the moment we cannot.

Jones et al. (1966) suggested that the expression "Turner's phenotype " should be used to indicate the presence of sufficient Turner stigmata to arouse the clinical suspicion of Turner's syndrome but that unless dwarfism and streak gonads are confirmed the term should be suitably qualified. Thus " male Turner's syndrome" would become "Turner's male phenotype " and Ullrich's syndrome would become "Turner's phenotype with normal ovaries." On this basis the BonnevieUllrich syndrome could become "Turner's infantile phenotype." It is usually recognized in the neonatal period from the presence of oedema of feet and loose neck folds. The oedema is brawny but pits on pressure ; it occasionally also affects the hands. Both the oedema and the loose neck folds 